\title{
PENGARUH PENDAPATAN SEKTOR PARIWISATA TERHADAP KINERJA KEUANGAN DAERAH DI PROVINSI DIY DENGAN PERTUMBUHAN USAHA KECIL MENENGAH (UKM) SEBAGAI VARIABEL INTERVENING
}

\author{
Merynda Puspitaningrum \\ Program Studi Akuntansi Universitas Negeri Yogyakarta \\ meryndaphy@gmail.com
}

\begin{abstract}
Abstrak: Pengaruh Pendapatan Sektor Pariwisata Terhadap Kinerja Keuangan Daerah Di Provinsi Diy Dengan Pertumbuhan Usaha Kecil Menengah (Ukm) Sebagai Variabel Intervening. Penelitian ini bertujuan untuk mengetahui pengaruh Pendapatan Sektor Pariwisata terhadap Kinerja Keuangan Daerah dan pengaruh Pendapatan Sektor Pariwisata terhadap Kinerja Keuangan Daerah dengan Pertumbuhan UKM sebagai variabel intervening. Subjek penelitian dalam penelitian ini adalah Provinsi Daerah Istimewa Yogyakarta (DIY). Objek penelitian dalam penelitian ini adalah Pendapatan Sektor Pariwisata tahun 2006 2012 Kabupaten/Kota di Provinsi DIY, Kinerja Keuangan Daerah tahun 2006 - 2012 Kabupaten/Kota di Provinsi DIY, dan Pertumbuhan UKM tahun 2006 -2012 Kabupaten/Kota di Provinsi DIY. Teknik pengumpulan data dalam penelitian ini adalah dokumentasi. Teknik analisis yang digunakan adalah analisis regresi sederhana dan analisis regresi ganda. Hasil dari penelitian ini menunjukkan bahwa Pendapatan Sektor Pariwisata berpengaruh terhadap Kinerja Keuangan Daerah dengan nilai $t_{\text {hitung }} 6,457$ lebih besar dari $t_{\text {tabel}}$, $(6,457>2,0301)$ dan signifikansi $0,000<0,05$. Penelitian ini juga menunjukkan hasil bahwa Pendapatan Sektor Pariwisata berpengaruh terhadap Kinerja Keuangan Daerah, tetapi Pertumbuhan UKM tidak mengintervening hubungan pengaruh Pendapatan Sektor Pariwisata terhadap Kinerja Keuangan Daerah. Hal tersebut ditunjukkan dengan nilai thitung sebesar - 0,01071454, lebih kecil dari tabel 2,0301 (-0,01071454 < $2,0301)$ dan signifikansi sebesar $0,256(0,256>0,05)$.
\end{abstract}

Kata kunci: Pendapatan Sektor Pariwisata, Kinerja Keuangan Daerah, Pertumbuhan UKM, Provinsi DIY.

\begin{abstract}
The Effect Of Tourism Sector Revenue To Regional Financial Performance In Diy Province With The Growth Of Small Medium Enterprise (Smes) As Intervening Variable. This research aims to determine the influence of Tourism Sector Revenue toward Regional Financial Performance, and the influence of Tourism Sector Revenue toward Regional Financial Performance with The Growth of SMEs as intervening variable. This research was conducted in Daerah Istimewa Yogyakarta (DIY) Province according to fiscal year 2006 - 2012. The research subjects in this study was Daerah Istimewa Yogyakarta (DIY) Province. The research object was the Tourism Sector Revenue in 2006 - 2012 Regency/City in DIY, Regional Financial Performance in 2006 - 2012 Regency/City in DIY, and The Growth of SMEs in 2006 2012 Regency /City in DIY. The collecting data technique was documentation. The analysis technique used in this research was simple regression analysis and multiple regression analysis. The results of this study were: (1) The Tourism Sector Revenue influences the Regional Financial Performance, as shown by $t_{c o u n t}$ $6.457>t_{\text {table }} 2.0301$ and sig. $0.000,(0.000<0.05)$. (2) The Tourism Sector Revenue influences the Regional Financial Performance, but The Growth of SMEs isn't as intervening variable, as shown by thitung 0,01071454 is smaller than ttable 0,256 and sig. 0,256 greater than $0.05(0,256>0,05)$.
\end{abstract}

Keywords: Tourism Sector Revenue, Regional Financial Performance, Growth SMEs, DIY Province. 


\section{JURNAL NOMINAL / VOLUME IV NOMOR 2 / TAHUN 2015}

\section{PENDAHULUAN}

Menurut Undang-Undang Nomor 32 Tahun 2004 (pengganti Undang-Undang Nomor 25 Tahun 1999) tentang Pemerintah Daerah, Otonomi Daerah adalah hak, wewenang, dan kewajiban daerah otonom untuk mengatur dan mengurus sendiri urusan pemerintah dan kepentingan masyarakat setempat sesuai dengan peraturan perundang-undangan. Diteruskan dengan pasal 1 yang menjelaskan bahwa dalam pelaksanaan Otonomi Daerah terdapat empat elemen penting yang diserahkan Pemerintah Pusat kepada Pemerintah Daerah. Keempat elemen tersebut adalah Desentralisasi Politik, Desentralisasi Fiskal, Desentralisasi Administrasi dan Desentralisasi Ekonomi. Konsekuensi dari adanya Otonomi Daerah, maka harus disertai dengan peningkatan kinerja dan akuntabilitas pemerintah daerah agar tujuan desentralisasi kekuasaan dapat tercapai. Kenyataan yang terjadi adalah masih besarnya tingkat ketergantungan keuangan daerah terhadap pusat. Dana subsidi yang diberikan pemerintah pusat kepada daerah semakin meningkat dari tahun ke tahun.

Daerah Istimewa Yogyakarta

(DIY) merupakan salah satu daerah otonom di tingkat provinsi. Terdapat 4 kabupaten dan 1 kota di DIY, yaitu Kabupaten Kulon Progo, Kabupaten Bantul, Kabupaten Sleman, Kabupaten Gunung Kidul, dan Kota Yogyakarta. Ketergantungan terhadap pemerintah pusat di DIY juga masih cukup tinggi. Hal tersebut dapat dilihat dalam struktur APBD DIY pada tahun 2010 menunjukkan bahwa proporsi transfer dari pusat sebesar 77,3\% lebih tinggi daripada Pendapatan Asli Daerah yang hanya $12,8 \%$. Sektor pariwisata di DIY memang sangat potensial sebagai salah satu penyumbang PAD. Salah satu sumber PAD, yakni pajak dan retribusi daerah. Potensi wisata yang terdapat di Provinsi DIY tersebar di setiap kabupaten/kota. Setiap daerah memiliki daya tarik wisata masing-masing. Sektor ini berpotensi untuk menggerakkan perekonomian di suatu wilayah, dalam hal ini Provinsi DIY.

Spillane (1994) dalam Kesatria (2010) menerangkan bahwa kegiatan pariwisata menciptakan permintaan, baik konsumsi, maupun investasi yang pada gilirannya akan menimbulkan kegiatan produksi barang dan jasa. Selama berwisata, wisatawan akan melakukan kegiatan belanja, sehingga secara langsung menimbulkan permintaan pasar barang dan jasa yang istilahnya disebut Tourism Final Demand. Selanjutnya Tourism Final Demand wisatawan secara tidak langsung menimbulkan permintaan akan barang modal dan bahan baku untuk berproduksi memenuhi permintaan wisatawan akan barang dan jasa tersebut yang istilahnya disebut Investment Derived Demand. Dalam usaha untuk memenuhi permintaan wisatawan diperlukan investasi di bidang transportasi, komunikasi, perhotelan dan akomodasi lain, industri kerajinan dan industri produk konsumen, industri jasa, rumah makan, restoran dan lain-lain. Hal tersebut merujuk pada perkembangan dan pertumbuhan UKM. Unit usaha UKM akan beragam sebagai penyedia permintaan wisatawan, baik barang maupun jasa. 


\section{JURNAL NOMINAL / VOLUME IV NOMOR 2 / TAHUN 2015}

Keadaan tersebut dari tahun ke tahun semakin meningkat, pertumbuhan UKM di Yogyakarta juga meningkat. UKM juga potensial berkontribusi menyumbang PAD melalui pajak daerah yang dibebankan kepada pelaku UKM. Dalam penelitian ini menggunakan Pertumbuhan Usaha Kecil Menegah (UKM) sebagai variabel intervening sebagai bentuk modifikasi dari penelitian terdahulu yang dilakukan oleh $\mathrm{Ni}$ Komang Widiastuti pada tahun 2011. Pertumbuhan UKM dipilih sebagai variabel yang membuat hubungan tidak langsung antara variabel bebas dan terikat karena melihat kondisi lapangan di Provinsi DIY ini memang banyak bermunculan UKM yang menjadi penggerak perekonomian masyarakat dengan memanfaatkan kearifan lokal Yogyakarta dan memang lingkungan mendukung tumbuh kembang UKM. Sisi positif dari banyaknya jumlah pelaku UKM di DIY juga dirasakan pemerintah daerah, di mana pemungutan pajak dari pelaku UKM akan memberikan dampak positif bagi keuangan daerah.

Oleh karena itu, penelitian ini akan memberikan dukungan positif untuk perkembangan Kinerja Keuangan Daerah di Provinsi DIY. Peningkatan kinerja keuangan dengan mengoptimalkan pemanfaatan dan pengembangan potensi dan sumber daya yang terdapat di daerah secara efektif dan efisien.

Berdasarkan uraian di atas, penelitian ini bertujuan untuk mengetahui (1) Pengaruh Pendapatan Sektor Pariwisata terhadap Kinerja Keuangan Daerah (2) Pengaruh Pendapatan
Sektor Pariwisata terhadap Kinerja Keuangan Daerah di Provinsi Daerah Istimewa Yogyakarta dengan Pertumbuhan Usaha Kecil Menengah (UKM) sebagai Variabel Intervening.

\section{METODE PENELITIAN}

\section{Jenis Penelitian}

Berdasarkan karakteristiknya, penelitian ini termasuk dalam penelitian korelasioanl. Penelitian Korelasional merupakan tipe penelitian dengan karakteristik masalah berupa hubungan korelasi antara dua variabel atau lebih. Dalam penelitian ini hubungan korelasional yang diteliti adalah Kinerja Keuangan Daerah di Provinsi DIY sebagai variabel dependen dan Pendapatan Sektor Pariwisata sebagai variabel independen. Untuk penelitian ini penulis menambahkan satu variabel, yaitu Pertumbuhan UKM sebagai variabel intervening.

Berdasarkan jenis data yang diteliti, penelitian ini termasuk penelitian arsip. Penelitian Arsip (Archival Research) merupakan penelitian terhadap fakta yang tertulis (dokumen) atau berupa arsip data. Dalam penelitian ini dibutuhkan data yang berhubungan dengan variabel-variabel penelitian. Data tersebut diperoleh dari Badan Pusat Statistik (BPS), Dinas Pariwisata (Dinpar) DIY dan Dinas Perindustrian Perdagangan Koperasi dan UKM (Disperindagkop dan UKM) DIY dengan mengajukan surat permohonan untuk melakukan penelitian terkait data. Penelitian ini menggunakan jenis data sekunder, yaitu penelitian terhadap arsip, yang merupakan data 


\section{JURNAL NOMINAL / VOLUME IV NOMOR 2 / TAHUN 2015}

internal yang ada di Pemerintah Daerah Provinsi DIY.

\section{Tempat dan Waktu Penelitian}

Penelitian dilakukan di Pemerintah Daerah Provinsi Daerah Istimewa Yogyakarta melalui Badan Pusat Statistik (BPS), Dinas Pariwisata (Dinpar), dan Dinas Perindustrian, Perdagangan, Koperasi dan UKM (Disperindagkop dan UKM). Waktu penelitian dilakukan pada bulan Januari Maret 2015.

\section{Subjek dan Objek Penelitian}

Subjek penelitian dalam penelitian ini adalah Provinsi Daerah Instimewa Yogyakarta. Objek penelitian dalam penelitian ini adalah Pendapatan Sektor Pariwisata tahun 2006 - 2012 Kabupaten/Kota di Provinsi DIY, Kinerja Keuangan Daerah tahun 2006 - 2012 Kabupaten/Kota di Provinsi DIY, dan Pertumbuhan UKM tahun 2006 - 2012 Kabupaten/Kota di Provinsi DIY.

\section{Teknik Pengumpulan Data}

Metode yang digunakan untuk pengumpulan data adalah dokumentasi, yaitu mengumpulkan data sekunder dengan cara melihat atau menyalin catatan kertas kerja yang dianggap berhubungan dengan penelitian. Data sekunder merupakan sumber data penelitian yang diperoleh peneliti secara tidak langsung melalui media perantara (diperoleh dan dicatat pihak lain). Data sekunder umumnya berupa bukti, catatan atau laporan historis yang telah tersusun dalam arsip (data dokumenter) yang dipublikasikan dan yang tidak dipublikasikan (Nur Indriantoro dan Supomo, 2013: 147).
Data yang dibutuhkan dalam penelitian ini terdapat dalam buku statistik yang diterbitkan BPS, Dinpar DIY, dan Disperindagkop dan UKM DIY yang sifatnya terbuka untuk umum. Pengumpulan data dilakukan dengan mendokumentasikan data yang dibutuhkan dalam buku statistik yang terdapat di perpustakaan kantor BPS DIY. Data yang dipakai dalam penelitian adalah:

a. Data Statistik Keuangan dengan melihat pada Realisasi Penerimaan masing-masing Kabupaten/Kota yang ada di Provinsi DIY tahun $2006-2012$.

b. Data Statistik Kepariwisataan dengan melihat pada kontribusi sektor pariwisata terhadap PAD yang ada di masing - masing Kabupaten/Kota di Provinsi DIY tahun 2006 -2012 .

c. Data Statistik Disperindagkop dan UKM dengan melihat pada jumlah UKM di Provinsi DIY tahun 2005 - 2012.

\section{Teknik Analisis Data}

Penelitian ini menggunakan data sekunder untuk keseluruhan variabel, yaitu Pendapatan Sektor Pariwisata, Kinerja Keuangan Daerah, dan Pertumbuhan UKM. Berikut ini adalah tahapan analisis data:

\section{Uji Asumsi Klasik}

\section{Uji Normalitas}

Uji normalitas bertujuan untuk menguji apakah dalam model regresi variabel penggangu atau residual memiliki distribusi normal. Untuk menguji normalitas data, terdapat dua cara yang digunakan, yaitu analisis grafik dan analisis 


\section{JURNAL NOMINAL / VOLUME IV NOMOR 2 / TAHUN 2015}

statistik. Jika data menyebar di sekitar garis diagonal atau grafik histogramnya menunjukkan pola distribusi normal, maka model regresi memenuhi asumsi normalitas. Sebaliknya, jika data menyebar jauh dari diagonal dan atau tidak mengikuti garis diagonal atau histogram menunjukkan pola distribusi yang tidak normal, maka model regresi tidak memenuhi asumsi normalitas. Normalitas juga dapat dilihat dengan membandingkan nilai kurtosis dan skewness dari residual. Jika nilai $\mathrm{Z}$ hitung $>\mathrm{Z}$ tabel, maka distribusi tidak normal (Imam Ghozali, 2011).

\section{Uji Autokorelasi}

Uji autokorelasi bertujuan untuk menguji apakah model regresi linier ada korelasi antarkesalahan pengganggu (residual) periode $t$ dengan kesalahan pada periode t-1 (sebelumnya) Pengujian dilakukan dengan Durbin-Watson (DW). Bila hasil uji D-W di bawah -2 berarti terjadi autokorelasi positif, hasil DW yang menunjukkan antara -2 dan 2, maka tidak terjadi autokorelasi dan jika hasil uji bernilai di atas +2 , maka terjadi autokorelasi negatif (Imam Ghozali, 2011).

\section{Uji Heteroskedastisitas}

Uji heteroskedastisitas bertujuan untuk menguji apakah dalam model regresi terjadi ketidaksamaan varian dari residual satu pengamatan ke pengamatan yang lain. Jika variance dari residual satu pengamatan ke pengamatan lain tetap maka disebut homokedastisitas dan jika berbeda disebut heteroskedastisitas. Model regresi yang baik adalah yang bersifat homokedastisitas. Penelitian ini menggunakan Uji Glejser. Kriteria pengambilan keputusan adalah jika signifikansi dari variabel bebas lebih besar dari 0,05 maka tidak terjadi heteroskedastisitas (Imam Ghozali, 2011).

\section{Pengujian Hipotesis}

Untuk menguji hipotesis dalam penelitian ini, berdasarkan Gambar 2 halaman 32 pada Paradigma Penelitian, peneliti memecah gambar menjadi dua bagian, yaitu Panel A dan Panel B Panel A

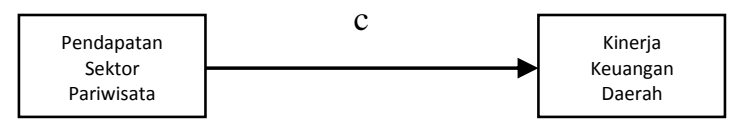

Panel B

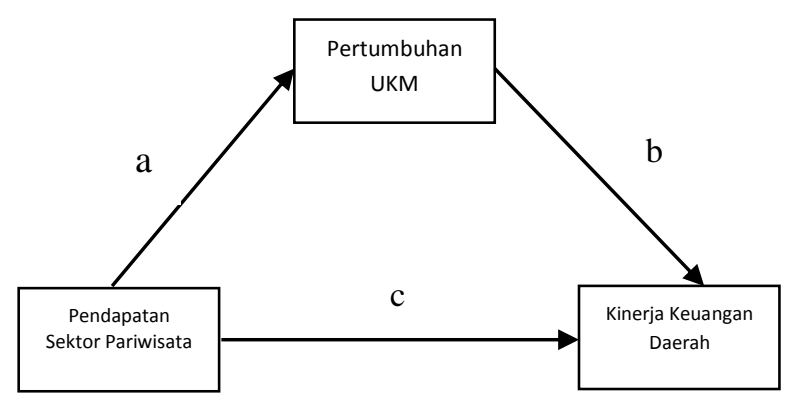

Keterangan:

a,b,c, c' $=$ koefisien regresi

Gambar 1. Panel A Pengaruh Pendapatan Sektor Pariwisata terhadap Kinerja Keuangan Daerah dan Panel B Pengaruh Pendapatan Sektor Pariwisata terhadap Kinerja Keuangan Daerah dengan Pertumbuhan UKM sebagai variabel intervening 


\section{JURNAL NOMINAL / VOLUME IV NOMOR 2 / TAHUN 2015}

Gambar Panel A menggambarkan Hipotesis H1, bahwa Pendapatan Sektor Pariwisata berpengaruh langsung terhadap Kinerja Keuangan Daerah. Panel B menggambarkan Hipotesis H2, bahwa Pendapatan Sektor Pariwisata berpengaruh terhadap Kinerja Keuangan Daerah dengan Pertumbuhan UKM sebagai variabel intervening.

\section{Analisis Regresi}

Adanya pengaruh variabel intervening dapat dideteksi secara langsung dengan melihat pada Gambar 3. Berdasarkan pada Gambar 3 Panel A dan Panel B, diperoleh persamaan regresi sebagai berikut:

$$
\begin{aligned}
& Y=a 1+c X \\
& Z=a 2+\mathrm{a} X \\
& Y^{\prime}=a 3+c^{\prime} X+b Z
\end{aligned}
$$

Keterangan :

\section{X : Pendapatan Sektor Pariwisata}

Y : Kinerja Keuangan Daerah yang dipengaruhi Pendapatan Sektor Pariwisata

Y' : Kinerja Keuangan Daerah yang dipengaruhi Pendapatan Sektor Pariwisata dengan Pertumbuhan UKM sebagai variabel intervening

Z : Pertumbuhan UKM

A : Konstanta

\section{a, $b, c, c^{\prime}: \quad$ koefisien regresi}

Variabel $\mathrm{Z}$ disebut intervening atau mediator jika persamaan (1) X secara signifikan mempengaruhi $\mathrm{Y}$ (atau $c \neq 0$ ), persamaan (2) X secara signifikan mempengaruhi $\mathrm{Z}$ (atau $\mathrm{a} \neq 0$ ), dan persamaan (3) X secara signifikan mempengaruhi Y dengan mengontrol $\mathrm{X}$ (atau $b$ $\neq 0)$.
Jika pengaruh $\mathrm{X}$ terhadap $\mathrm{Y}$ menurun menjadi nol (0) dengan memasukkan variabel Z, maka terjadi mediasi sempurna (perfect mediation). Namun demikian, jika pengaruh $\mathrm{X}$ terhadap $\mathrm{Y}$ menurun tidak sama dengan nol dengan memasukkan variabel $\mathrm{Z}$, maka terjadi mediasi parsial (partial mediation) (Imam Ghozali, 2011). Standard eror koefisien a dan b ditulis dengan Sa dan Sb dan besarnya standard eror pengaruh tidak langsung (indirect effect) adalah Sab yang dihitung dengan rumus:

$s_{a b}=\sqrt{b^{2} s a^{2}+a^{2} s b^{2}+s a^{2} s b^{2}}$

\section{Uji Signifikansi dengan Uji t}

Untuk menguji signifikansi pada hipotesis pertama yaitu dengan melihat nilai $t_{\text {hitung }}$ pada hasil analisis regresi kemudian membandingkannya dengan nilai $t_{\text {tabel. }}$ Jika nilai $t_{\text {hitung }}>\mathrm{t}_{\text {tabel }}$ menunjukkan bahwa pengaruh variabel independen terhadap variabel depanden signifikan.

Untuk menguji signifikansi pada hipotesis kedua, yaitu mengetahui pengaruh langsung atau tidak langsung variabel independen terhadap variabel dependen dengan adanya variabel intervening. Perhitungan nilai $\mathrm{t}$ dari koefisien ab dengan rumus: $\quad t=\frac{a b}{s a b}$

Kriteria pengujian dengan menbandingkan nilai $t_{\text {hitung }}$ dengan $t_{\text {tabel. }}$. Jika nilai $t_{\text {hitung }}>$ nilai $t_{\text {tabel }}$, mka dapat disimpulkan terjadi pengaruh mediasi (Imam Ghozali, 2011). 


\section{JURNAL NOMINAL / VOLUME IV NOMOR 2 / TAHUN 2015}

HASIL PENELITIAN DAN PEMBA-

\section{HASAN}

\section{Data Khusus}

a. Kinerja Keuangan Daerah 2006 - 2012

Berikut ini adalah ketiga rasio pengukuran Kinerja Keuangan Daerah dan cara menghitungnya:

1) Rasio Kemandirian Keuangan Daerah Pendapatan Asli Daerah (PAD) Dana Perimbangan

2) Rasio Ketergantungan Keuangan Daerah

Pendapatan Asli Daerah (PAD) Total Penerimaan APBD tanpa subsidi

3) Rasio Desentralisasi Fiskal Pendapatan Asli Daerah (PAD) Total Penerimaan Daerah (TPD)

(Abdul Halim, 2008)

\section{b. Pendapatan Sektor Pariwisata}

Pendapatan Sektor Pariwisata merupakan penghasilan dalam bentuk sejumlah uang yang diperoleh dari aktivitas - aktivitas kepariwisataan yang terjadi di suatu daerah, dalam hal ini daerah Provinsi DIY. Pendapatan Sektor Pariwisata juga berperan penting sebagai sumber PAD bagi sebuah daerah otonom.

Indikator yang dipilih untuk mengukur Pendapatan Sektor Pariwisata ada lima, yaitu (a) kontribusi pajak hotel dan restoran; (b) kontribusi pajak tontonan/hiburan; (c) kontribusi retribusi ODTW (Objek Daya Tarik Wisata); (d) retribusi perizinan usaha pariwisata; dan (e) retribusi penggunaan aset milik Pemda. Kelima indikator tersebut dilihat kontribusinya terhadap PAD. Data yang digunakan dalam penelitian ini dari tahun 2006 -2012 .

\section{c. Pertumbuhan UKM}

Pertumbuhan UKM merupakan suatu keadaan yang menunjukkan adanya perubahan jumlah unit UKM yang meningkat dari waktu ke waktu. Penelitian ini melihat Pertumbuhan UKM yang terjadi di Provinsi DIY dari tahun 2006 2012. Suatu keadaan dapat dikatakan tumbuh apabila mengalami perbedaan yang dapat diukur secara kuantitatif. Untuk mengetahui Pertumbuhan UKM dari tahun 2006 - 2012, peneliti menggunakan data jumlah UKM dari tahun 2005 - 2012. Pertumbuhan UKM dilihat dari selisih jumlah UKM tahun yang bersangkutan dengan jumlah UKM tahun sebelumnya sehingga dapat diketahui berapa besar pertumbuhannya.

Tabel 1. Data Penelitian

\begin{tabular}{cccc}
\hline No & $\begin{array}{c}\text { Pendapatan } \\
\text { Sektor } \\
\text { Pariwisata } \\
\text { (Variabel X) }\end{array}$ & $\begin{array}{c}\text { Kinerja } \\
\text { Keuangan } \\
\text { Daerah } \\
\text { (Variabel Y) }\end{array}$ & $\begin{array}{c}\text { Pertumbuhan } \\
\text { UKM } \\
\text { (Variabel Z) }\end{array}$ \\
\hline $\mathbf{1}$ & 0,009072086 & 1,110239625 & 0,004297 \\
\hline $\mathbf{2}$ & 0,035129673 & 0,995173733 & 0,004297 \\
\hline $\mathbf{3}$ & 0,265822414 & 1,042120495 & 0,004297 \\
\hline $\mathbf{4}$ & 0,366581973 & 1,277171244 & 0,004297 \\
\hline $\mathbf{5}$ & 0,536447581 & 1,236549381 & 0,004297 \\
\hline $\mathbf{6}$ & 0,010971466 & 0,635788642 & 0,041417 \\
\hline $\mathbf{7}$ & 0,037193336 & 0,63177396 & 0,041417 \\
\hline $\mathbf{8}$ & 0,001179949 & 0,514668416 & 0,041417 \\
\hline $\mathbf{9}$ & 0,175112246 & 0,956833464 & 0,041417 \\
\hline $\mathbf{1 0}$ & 0,279899194 & 1,091628709 & 0,041417 \\
\hline $\mathbf{1 1}$ & 0,014963046 & 0,751475809 & 0,003965 \\
\hline $\mathbf{1 2}$ & 0,046950982 & 0,28903783 & 0,003965 \\
\hline $\mathbf{1 3}$ & 0,055369773 & 0,476439171 & 0,003965 \\
\hline $\mathbf{1 4}$ & 0,353646192 & 0,860724056 & 0,003965 \\
\hline $\mathbf{1 5}$ & 0,329763316 & 1,0652192 & 0,003965 \\
\hline $\mathbf{1 6}$ & 0,013301177 & 0,530884737 & 0,015174 \\
\hline $\mathbf{1 7}$ & 0,051397644 & 0,64831799 & 0,015174 \\
\hline $\mathbf{1 8}$ & 0,044185866 & 0,49196452 & 0,015174 \\
\hline $\mathbf{1 9}$ & 0,200775815 & 0,941515549 & 0,015174 \\
\hline & & & \\
\hline
\end{tabular}


JURNAL NOMINAL / VOLUME IV NOMOR 2 / TAHUN 2015

\begin{tabular}{lccc}
\hline $\mathbf{2 0}$ & 0,28821602 & 1,221592983 & 0,015174 \\
\hline $\mathbf{2 1}$ & 0,036267574 & 0,672254629 & 0,01908 \\
\hline $\mathbf{2 2}$ & 0,056495947 & 0,70235501 & 0,01908 \\
\hline $\mathbf{2 3}$ & 0,046426398 & 0,539110888 & 0,01908 \\
\hline $\mathbf{2 4}$ & 0,249092574 & 0,942587841 & 0,01908 \\
\hline $\mathbf{2 5}$ & 0,282346903 & 1,282414989 & 0,01908 \\
\hline $\mathbf{2 6}$ & 0,021911828 & 0,370218199 & 0,01955 \\
\hline $\mathbf{2 7}$ & 0,057403896 & 0,567064115 & 0,01955 \\
\hline $\mathbf{2 8}$ & 0,04239634 & 0,32648919 & 0,01955 \\
\hline $\mathbf{2 9}$ & 0,171795847 & 0,88012 & 0,01955 \\
\hline $\mathbf{3 0}$ & 0,246288794 & 1,205068047 & 0,01955 \\
\hline $\mathbf{3 1}$ & 0,038878793 & 0,434757153 & 0,00198 \\
\hline $\mathbf{3 2}$ & 0,103045073 & 0,613433134 & 0,00198 \\
\hline $\mathbf{3 3}$ & 0,152494826 & 0,375070807 & 0,00198 \\
\hline $\mathbf{3 4}$ & 0,241392119 & 0,872811333 & 0,00198 \\
\hline $\mathbf{3 5}$ & 0,318595734 & 1,430748834 & 0,00198 \\
\hline
\end{tabular}

\begin{tabular}{lr}
\hline \multicolumn{1}{c}{ Keterangan } & Unstandardized Residual \\
& \\
\hline $\mathrm{N}$ & 35 \\
\hline Kolmogorov-Smirnov $Z$ & 0,763 \\
\hline Asymp. Sig. (2-tailed) & 0,606 \\
\hline a. Test distribution is Normal. & \\
\hline
\end{tabular}

Sumber: Data Sekunder yang Diolah, 2015

Nilai Kolmogorov-Smirnov $Z \quad 0,763$ dan nilai Asymp Sig 0,606 > 0,05 maka dapat disimpulkan bahwa data berdistribusi normal.

\section{Uji Autokorelasi}

Tabel 4. Hasil Uji Autokolerasi dengan Uji Durbin-Watson

\section{Hasil Uji Statistik dan Pembahasan}

\section{Uji Normalitas}

\section{Tabel 2. Hasil Uji Normalitas Variabel Pendapatan Sektor Pariwisata terhadap Kinerja Keuangan daerah}

\begin{tabular}{cc}
\hline Keterangan & Unstandardized Residual \\
\hline $\mathrm{N}$ & 35 \\
\hline Kolmogorov-Smirnov $Z$ & 0,663 \\
\hline Asymp. Sig. (2-tailed) & 0,772 \\
\hline a. Test distribution is Normal. & \\
\hline
\end{tabular}

Sumber: Data Sekunder yang Diolah, 2015

Nilai Kolmogorov-Smirnov $Z \quad 0,663$ dan nilai Asymp Sig 0,772 > 0,05 maka dapat disimpulkan bahwa data berdistribusi normal.

Tabel 3. Hasil Uji Normalitas Variabel Pendapatan Sektor Pariwisata dan Pertumbuhan UKM terhadap Kinerja Keuangan Daerah

\section{Uji Heteroskedasitas}

Tabel 5. Hasil Uji Heteroskedastisitas Variabel Pendapatan Sektor Pariwisata terhadap Kinerja Keuangan Daerah

\begin{tabular}{llc}
\hline Model & & Sig. \\
\hline \multirow{2}{*}{1} & $($ Constant $)$ & 1,000 \\
\cline { 2 - 3 } & Pendapatan Sektor Pariwisata & 1,000 \\
\hline
\end{tabular}




\section{JURNAL NOMINAL / VOLUME IV NOMOR 2 / TAHUN 2015}

Hasil uji Glejser di atas menunjukkan bahwa tidak ada satupun variabel independen yang signifikan secara statistik mempengaruhi variabel dependen. Hal ini terlihat dari probabilitas signifikansinya di atas $5 \%(0,05)$, yaitu sebesar 1,000. Jadi dapat disimpulkan bahwa model regresi tidak mengandung adanya heteroskedastisitas

Tabel 6. Hasil Uji Heteroskedasitas Variabel Pendaatan Sektor Pariwisata dan Pertumbuhan UKM terhadap Kinerja Keuangan Daerah

\begin{tabular}{llr}
\hline \multicolumn{2}{c}{ Model } & Sig. \\
& & \\
\hline \multirow{2}{*}{1} & (Constant) & 1,000 \\
\cline { 2 - 2 } & Pendapatan Sektor Pariwisata & 1,000 \\
\cline { 2 - 2 } & Pertumbuhan UKM & 1,000 \\
\hline \multicolumn{2}{l}{ Sumber : Data Sekunder yang Diolah, 2015} \\
\hline
\end{tabular}

\section{Uji Hipotesis I}

Tabel 7. Ringkasan Hasil Regresi Linier Sederhana Pendapatan Sektor Pariwisata terhadap Kinerja Keuangan Keuangan

\begin{tabular}{ll}
\hline Variabel Independen & $\begin{array}{l}\text { Pendapatan } \\
\text { Pariwisata }\end{array}$ \\
\hline Variabel Dependen & Kinerja Keuangan Daerah \\
\hline $\mathbf{R}^{\mathbf{2}}$ & 0,558 \\
\hline $\mathbf{t}_{\text {hitung }}$ & 6,457 \\
\hline tabel & 2,0301 \\
\hline Signifikansi & 0,000 \\
\hline Konstanta & 0,548 \\
\hline Koefisien & 1,775
\end{tabular}

Sumber: Data Sekunder yang Diolah, 2015

Persamaan regresi sebagai berikut:

$\mathrm{KKD}=0,548+1,775 \mathrm{PSP}$
Dari persamaan tersebut, diketahui nilai konstanta sebesar 0,548 yang berarti jika variabel Pendapatan Sektor Pariwisata (PSP) dianggap konstan, maka nilai Kinerja Keuangan Daerah adalah 0,548. Nilai koefisien regresi dalam persamaan tersebut yang menunjukkan angka sebesar 1,775 menjelaskan bahwa setiap peningkatan Pendapatan Sektor Pariwisata sebesar 1 poin, maka akan meningkatkan Kinerja Keuangan Daerah sebesar $1,775 \%$. Oleh karena koefisien regresi bernilai positif, maka dapat disimpulkan bahwa Pendapatan Sektor Pariwisata berpengaruh terhadap Kinerja Keuangan Daerah.

Nilai koefisien determinasi sebesar 0,558. Dari nilai tersebut dapat diartikan bahwa sebesar $55,8 \%$ variasi Kinerja Keuangan Daerah dapat dijelaskan oleh variasi Pendapatan Sektor Pariwisata, sedangkan sisanya sebesar 44,2\% (100\% $55,8 \%$ ) dijelaskan oleh faktor lain yang tidak dimasukkan dalam model ini.

Uji signifikansi dapat dilakukan dengan membandingkan nilai $t_{\text {hitung }}$ dengan nilai tabel atau dapat pula dilakukan dengan membandingkan nilai probabilitas signifikansi dengan nilai pada tingkat signifikansi yang telah ditentukan, yaitu sebesar 0,05. Tabel 15 menunjukkan nilai thitung sebesar 6,457 jika dibandingkan dengan nilai tabel untuk $\mathrm{n}$ sebanyak 35 pada tingkat signifikansi 0,05 sebesar 2,0301, maka nilai thitung lebih besar dari nilai $\mathrm{t}_{\text {tabel }}(6,457>2,0301)$. Nilai 


\section{JURNAL NOMINAL / VOLUME IV NOMOR 2 / TAHUN 2015}

probabilitas signifikansi sebesar 0,000 juga menunjukkan nilai yang lebih kecil dari nilai signifikansi yang telah ditentukan yaitu 0,05 $(0,000 \leq 0,05)$.

Berdasarkan hasil uji signifikansi dengan uji t tersebut, maka dapat disimpulkan bahwa variabel Pendapatan Sektor Pariwisata berpengaruh terhadap Kinerja Keuangan Daerah secara signifikan. Dengan demikian, hipotesis pertama yang menyatakan Pendapatan Sektor Pariwisata berpengaruh terhadap Kinerja Keuangan Daerah diterima.

a. Uji Hipotesis II

Tabel 8. Ringkasan Hasil Regresi Linier Pendapatan Sektor Pariwisata terhadap Pertumbuhan UKM

\begin{tabular}{lll}
\hline $\begin{array}{l}\text { Variabel } \\
\text { Independen }\end{array}$ & $\begin{array}{l}\text { Pendapatan } \\
\text { Pariwisata }\end{array}$ & Sektor \\
\hline Variabel Dependen & Pertumbuhan UKM \\
\hline $\mathbf{R}^{\mathbf{2}}$ & 0,058 \\
\hline $\mathbf{t}_{\text {hitung }}$ & $-1,432$ \\
\hline $\mathbf{t}_{\text {tabel }}$ & 2,0301 \\
\hline Signifikansi & 0,162 \\
\hline Konstanta & 0,018 \\
\hline Koefisien & $-0,023$
\end{tabular}

Sumber: Data Sekunder yang Diolah, 2015

Tabel 9. Ringkasan Hasil Regresi Linier Pendapatan Sektor Pariwisata, Pertumbuhan UKM terhadap Kinerja Keuangan Daerah

\begin{tabular}{llc}
\hline Variabel Independen & \multicolumn{2}{l}{ Kinerja Keuangn Daerah } \\
\hline Variabel Dependen & \multicolumn{2}{l}{ Pendapatan Sektor Pariwisata } \\
\hline Variabel Intervening & \multicolumn{2}{l}{ Pertumbuhan UKM } \\
\hline $\mathbf{R}^{\mathbf{2}}$ & 0,576 & - \\
\hline $\mathbf{t}_{\text {hitung }}$ & 6,577 & 1,156 \\
\hline $\mathbf{t}_{\text {tabel }}$ & 2,0301 & 2,0301 \\
\hline Signifikansi & 0,162 & 0,000 \\
\hline Konstanta & 0,484 & 0,484 \\
\hline Koefisien & 1,854 & 3,464
\end{tabular}

Sumber: Data Sekunder yang Diolah, 2015

Persamaan Regresi

(1) $\mathrm{PU}=0,018+(-0,023) \mathrm{PSP}$

(2) $\mathrm{KKD}=0,484+1,854 \mathrm{PSP}+3,464 \mathrm{PU}$

Hipotesis kedua dalam penelitian ini yang menyatakan bahwa Pendapatan Sektor Pariwisata berpengaruh terhadap Kinerja Keuangan Daerah dengan Pertumbuhan UKM sebagai variabel intervening. Berdasarkan hasil uji hipotesis menggunakan SPSS 16.0 For Windows, hasil penelitian menunjukkan bahwa Pendapatan Sektor Pariwisata berpengaruh terhadap Kinerja Keuangan, tetapi Pertumbuhan UKM tidak mengintervening hubungan pengaruh Pendapatan Sektor Pariwisata terhadap Kinerja Keuangan Daerah. Hal tersebut dapat diketahui dari hasil analisis regresi yang uji t dan signifikansi juga menunjukkan bahwa tidak ada pengaruh intervening dari Pertumbuhan UKM, di mana nilai thitung sebesar 0,01071454 lebih kecil dari nilai $t_{\text {tabel }}$ sebesar 2,0301 dan nilai signifikansi sebesar 0,256 di mana angka tersebut lebih besar dari batas toleransi sebesar 0,05 .

Untuk menguji signifikansi pengaruh tidak langsung $t=\frac{a b}{s a b}$

$$
\begin{aligned}
\mathrm{t} & =\frac{(-0,023)(3,464)}{7,435876706} \\
& =-0,01071454
\end{aligned}
$$

Berdasarkan perhitungan dengan rumus di atas, diperoleh nilai $t_{\text {hitung }}$ sebesar - 0,01071454 jika dibandingkan dengan nilai tabel untuk $n$ sebanyak 35 pada tingkat signifikansi 0,05 sebesar 2,0301, maka nilai thitung jauh lebih kecil dari nilai tabel $(-0,01071454<2,0301)$. Nilai 


\section{JURNAL NOMINAL / VOLUME IV NOMOR 2 / TAHUN 2015}

probabilitas signifikansi sebesar $\quad 0,256$ menunjukkan nilai yang lebih besar dari nilai signifikansi yang telah ditentukan yaitu 0,05 .

\section{KESIMPULAN DAN SARAN}

\section{Kesimpulan}

a. Pendapatan Sektor Pariwisata berpengaruh terhadap Kinerja Keuangan di Provinsi DIY pada tahun 2006 - 2012. Hal ini ditunjukkan dengan nilai $t_{\text {hitung }}$ sebesar 7,620 yang lebih besar dari nilai $t_{\text {tabel }}$ yaitu 2,0301 (7,620 > 2,0301) dan nilai probabilitas signifikansi sebesar 0,000 yang lebih kecil dari tingkat signifikansi yang ditentukan, yaitu 0,05 $(0,000 \leq 0,05)$

b. Pendapatan Sektor Pariwisata berpengaruh terhadap Kinerja Keuangan Daerah, tetapi Pertumbuhan UKM tidak meng-intervening hubungan pengaruh Pendapatan Sektor Pariwisata terhadap Kinerja Keuangan Daerah. Perhitungan nilai $\mathrm{t}$ diperoleh nilai $\mathrm{t}_{\text {hitung }}$ sebesar $-0,01071454$ jika dibandingkan dengan nilai tabel untuk n sebanyak 35 pada tingkat signifikansi 0,05 sebesar 2,0301, maka nilai $t_{\text {hitung }}$ jauh lebih kecil dari nilai $t_{\text {tabel }}$ $(0,01071454<2,0301)$. Nilai probabilitas signifikansi sebesar 0,256 menunjukkan nilai yang lebih besar dari nilai signifikansi yang telah ditentukan yaitu 0,05 .

\section{Saran}

\section{a. Bagi Pemerintah Daerah}

Pemerintah daerah selaku yang berwenang dalam mengelola keuangan daerah sebaiknya lebih memaksimalkan sumber-sumber pendapatan daerah untuk meningkatkan kinerja keuangan di daerah sehingga mengurangi ketergantungan terhadap pemerinth pusat. Dalam penelitian ini, dinas yang terkait adalah Dinas Pariwisata di mana salah satu sumber pendapatan daerah berasal dari sektor pariwisata, maka potensi yang ada di masing-masing kabupaten/kota harus tetap dikembangkan agar mendukung kemandirian keuangan daerah.

Terkait dengan ketersediaan data, dinas pemerintahan sebaiknya menyajikan data-data statistik secara lengkap dan berkala agar dapat diakses masyarakat umum dengan mudah. Selain itu, data untuk kepentingan penelitian agar dipermudah aksesnya.

b. Bagi Masyarakat

Masyarakat selaku pengendali pemerintahan dapat mendukung program pemerintah dengan memberikan kritik dan saran terhadap kinerja pemerintah jika dilihat dari segi keuangan dengan diterbitkannya data statistik keuangan dan ditujukan untuk umum. Masyarakat juga bisa menyampaikan aspirasinya untuk pemerintahan yang lebih baik dengan cara-cara yang sesuai ketentuan. Oleh karena itu, kebijakan yang dibuat pemerintah akan sesuai kebutuhan masyarakatnya, terutama di daerah.

\section{c. Bagi Peneliti Selanjutnya}

Penelitian selanjutnya sebaiknya melakukan penelitian yang sejenis dan dapat menambahkan atau mengganti variabel dalam penelitian yang akan dilakukan. 


\section{JURNAL NOMINAL / VOLUME IV NOMOR 2 / TAHUN 2015}

\section{DAFTAR PUSTAKA}

Abdul Halim. (2008). Akuntansi Sektor PublikAkuntansi Keuangan Daerah. Jakarta: Salemba Empat.

Ayu Febrianti Puspitasari. (2012). “Analisis Kinerja Keuangan Pemerintah Daerah Kota Malang Tahun Anggaran 20072011.” Skripsi. Malang. Fakultas Ekonomika dan Bisnis Universitas Brawijaya.

Dinas Pariwisata. (2013). Ringkasan Statistik Pariwisata Dinas Pariwisata. Yogyakarta: Dinas Pariwisata Provinsi DIY.

Dinas Perindustrian Perdagangan Koperasi dan UKM Pemerintah Daerah Daerah Istimewa Yogyakarta (Disperindagkop) melalui http://disperindagkop.jogjaprov.go.id/ pada 7 November 2014.

Ferry Pleanggra. (2012). "Analisis Pengaruh Jumlah Obyek Wisata, Jumlah
Wisatawan dan Pendapatan Perkapita Terhadap Pendapatan Retribusi Obyek Pariwisata 35 Kabupaten/Kota di Jawa Tengah.” Skripsi. Semarang: Fakultas Ekonomika dan Bisnis Universitas Diponegoro

Imam Ghozali. (2011). Aplikasi Analisis Multivariate dengan Program IBM SPSS 19. Semarang: Badan Penerbit Universitas Diponegoro

Spillane, James J. (1991). Ekonomi Pariwisata : Sejarah dan Prospeknya. Yogyakarta: Penerbit Kanisius.

Kesatria Sipayung. (2011). "Analisa Penerimaan Pariwisata dan Faktor-Faktor yang Mempengaruhi di Sepuluh Kabupaten/Kota Di Provinsi Sumatera Utara Periode 2005 - 2010.” Skripsi. MET - FEB Universitas Padjadjaran Bandung 